toxic antiviral agent isolated by Vavra et al. (The Upjohn Co.) from Streptomyces canarius. (7) $L L$-AP191, a xanthomycin-type antibiotic inhibiting both Grampositive and Gram-negative bacteria according to $\mathrm{H}$. A. Whaley et al. (Lederle Laboratories). (8) $L L-A 1471 E$, a macrolide antibiotic inhibiting Gram-positive bacteria, reported by M. P. Kunstmann et al. (Lederle Laboratories). (9) U-11092, an antibiotic inhibiting Gram-positive bacteria in vivo when given either per os or subcutaneously, according to B. K. Bhuyan et al. (The Upjohn Co.). (10) Enteromycin (seligocidin) from a streptozotocin-producing fermentation, as reported by R. R. Herr et al. (The Upjohn Co.). (11) Enteromycin carboxamide isolated by S. DeVoe et al. (Lederle Laboratories) from a streptomycete fermentation.

A wide variety of topics were discussed in the sessions concerned with clinical problems and treatment in humans: (1) Animal infections examinations which were pertinent to understanding host resistance and drug action, which included: pneumococcal infections in splenectomized monkeys; prophylaxis of aerogenic Rocky Mountain spotted fever in monkeys; experimental histoplasmosis capsulation endocarditis; coxsackie $A .9$ infection in adult mice treated with steroids and in mice with forced exercise; penicillin toxicity in guinea-pigs as related to changes in microbial flora; and renal infection with enterococcal protoplasts (in rats). (2) Clinical investigations concerned several chronic conditions, which included: fungal diseases in reticuloendothelial malignancies; infection in volunteers with penicillin-resistant gonococci; staphylococcal carriers; chronic bronchitis and pulmonary disease; retreatment of tuberculosis, Salmonella carriers, urinary tract infections and pathogenic studies in Gram-negative rod infections. (3) Studies of antibody responses, which included gonococcal and meningococcal infections, herpes simplex disease and staphylococcal states.
A series of papers on experimental infections covered: (1) Mycobacterium fortuitum in mice as a screen for tuberculosis; (2) hamycin in experimental mycoses in mice; (3) a standardized Leptospira pomona infection in hamsters; (4) experimental localized Pseudomonas infection (keratitis) in rabbits; (5) septicaemic anthrax in rhesus monkeys; (6) the use of sulphonamides in murine leprosy.

The modes of action of a number of antibiotics were mentioned, including $D$-cycloserine, vernamycin $A$, vancomycin, mitomycin $C$, porfiromycin and streptonigrin. Among the synthetic antimicrobial agents reported for the first time were an antifungal agent, tolnaftate $(O .2$. naphthyl- $m, N$-dimethylthiocarbanilate), 1-(5-nitrofurfurylideneamino)-2-imidazolidinone, and 4(5-nitro-2-furyl)-2-(3pyridyl)thiazole.

Most of the papers presented at the Conference will appear in Antimicrobial Agents and Chemotherapy, 1964, which will be published by the American Society for Microbiology (Ann Arbor, Michigan) in April 1965. The Proceedings will be distributed to all registrants at the meeting, and will be available from the American Society for Microbiology or from Messrs. H. K. Lewis, London.

Plans for the 1965 conference are already under way. This meeting will be combined with the fourth International Congress of Chemotherapy and will be jointly sponsored by the American Society for Microbiology and the International Society for Chemotherapy. Programmes on infectious diseases will be organized with the co-opera. tion of the Infectious Diseases Societ,y of America. The sessions will be held in the Shoreham Hotel, Washington, during October 17-2I. Dr. G. M. Savage (The Upjohn Co.) is general chairman, and enquiries concerning arrangements and participation should be sent to Mr. R. W. Sarber, Executive Secretary, American Society for Microbiology, 115 Huron View Boulevard, Ann Arbor, Michigan.
D. Perlman

\title{
METEOROLOGY AND LOCUST MIGRATIONS
}

$\mathrm{A}$

TECHNICAL Note recently published by the World Meteorological Organization covers a great deal of ground in the relationship between meteorology and the movement of locust populations*. Work on locust problems started in 1929 under Prof. B. P. Uvarov at what has now become the Anti-Locust Research Centre, and Dr. R. C. Rainey, who was a glider before the Second World War, a wartime meteorologist, and again an entomologist working with the Centre after the War, is uniquely qualified to write on meteorological aspects of locust populations. The note is very well produced, as are most of the World Meteorological Office Technical Note series, with 24 figures and three instructive photographs of locusts in flight, which hint at the problem - the immensity of which is realized by figures such as a swarm density per square kilometre of about $5 \times 10^{7}$ locusts, weighing $10^{5}$ kilograms and eating their own weight of vegetation each day. Swarms can cover hundreds or even thousands of square kilometres. As an example of financial loss, Morocco's loss in the year 1954-55 was assessed at about 13 million dollars; and Morocco was only one of 23 countries which suffered losses in that year.

The main emphasis is on the detailed survey for the year May 1954-May 1955, during which the Anti-Locust Research Centre collaborated closely with the World Meteorological Organization mission in East Africa headed

* World Meteorological Organization and Anti-Locust Research Centre. Meteorology and the Migration of Desert Locusts: Applications of Synoptic Meteorology in Locust Control. By R. C. Rainey. Pp. 115. (W.M.O. Technical Wote No. 54-No. 138. TP. 64. Anti-Locust Memoir No. 7.) (Geneva 1964.) $25 \mathrm{Sw}$. francs; 428 . by C. I. H. Aspliden, part author of Chapter 3. Considerable flying, both spotter and spraying, was undertaken, and swarm movements could be followed with far greater certainty than in any earlier work. Identifiable swarms flow for very variable distances up to $3,500 \mathrm{~km}$, with a maximum followed flight time of around two months. After a short introduction outlining the life cycle of the locust, meso-scale consideration is given to the individual swarm behaviour, and the general movement downwind is brought out clearly. Earlier investigations sometimes found variation between winds and swarm movements; this was presumably largely a question of difficultios of reliable assessment by ground observers, who could be unduly influenced by individual locust movements. Even in light winds, swarms nearly always moved more slowly than the surrounding air, although individual locusts may fly more quickly. 'This is caused by a sort of rolling effect, where the swarm 'front' rolls forward, with individual locusts spending some time on the ground if the swarm is low; flight level varied widely, however, with swarms at many thousands of feet on occasions. This agreement between wind and swarm movement is very valuable, as, for example, arrival of swarms in a new area can be foreseen.

The special survey year is documented with excellent monthly charts showing the locust distribution over the whole area from India westwards to Morocco, and includ. ing Central Africa; the development stage of the locust (whether hoppers, etc.) is also brought out. Each area is briefly discussed, with an analysis of locust behaviour during the year. 
Rainey puts forward the view that, broadly speaking, the locust populations are at their greatest to the south side of the Intertropical Convergence Zone (ICZ) and that frequently swarms of locusts follow by a day or two the northward moving ICZ. This is logical, since semitropical locusts must eventually get carried by northerly moving airstreams towards a convergence zone.

Locusts are essentially hot-climate insects, and the mostly light wind régimes which obtain in the semi-tropics do not give much opportunity for their movement outside the tropics. However, it does happen from time to time that an active depression tracking south of the Mediterranean carries the locusts bodily in the warm sector to areas north of the African coast. The classic migration example is quoted (with a trajectory map) of the locusts which reached the Isles of Scilly and Southern Ireland in October 1954-the first live locusts known to reach the British Isles since 1869. This type of trajectory technique has been applied more recently to moth migrations and spore movement with very similar types of track.
The pages of recommendations in Chapter 4 underline the importance of the type of collaboration found in meteorological networks and the inestimablo value of aircraft both for spotting and for spraying. The control of locust movement by low-level winds is brought out, and also the importance of the ICZ. About the only point with which on $\theta$ might quarrel is the suggestion of a relationship between sunspot activity and tho fluctuation of locust infestations which, viewed from a meteorological point of viow, sooms doubtful. Some of the diagrams such as those showing the effects of South Mediterranean depressions are not too happy; they have been stylized and appear distinctly confusing to a meteorologist.

There is no doubt of the value of the Note to anyone interested in either locust control problems or any insect migrations in general, and it is good to see such happy collaboration between such bodies as the AntiLocust Research Centre and the World Meteorological Organization.

G. W. HuRsT

\section{PROTECTION AGAINST IONIZING RADIATIONS}

\section{$\mathrm{T}$} HE informative and well-written Protection Against Ionizing Radiations*, issued by the World Health Organization, concerns legislation on protection against the use of ionizing radiations. Apart from an introductory chapter outlining the need for control and making a general survey of existing legislation, the book is principally a detailed account of the legislation in force in 26 different countries. On these grounds it cannot fail to be of interest and a constant souree of reference to all those concerned with radiological health and safcty.

The scope of legislation varies widely from country to country, revealing many interesting aspects of their developing use of ionizing radiations and national characteristics. In some countries, it is extremely detailed, covering almost every aspect of protection, while in others it is quite general in character and grcater reliance is placed on the voluntary action of users to maintain the required standards of safety. The need for legislation, in order to reduce the large numbers of accidents which were then taking place as a result of the uso of X-rays, was discussed in Germany as long ago as 1905 . Although no specific law resulted, nor is there any to-day in Germany covering the medical use of X-rays, the first rules for protection were drawn up and adopted in 1913 by the German Radiological Society. One of the earliest picess of legislation was the New York City Ordnance of 1922, controlling the use of X-ray equipment. In the same year a law was introduced in Italy concorning the prospecting for, and use of, radioactive substances. Othor countries introducing early legislation were Denmark, 1930 , on the use of X-rays, Netherlands, 1931, X-rays and radioactivo substances, and Finland, 1932, $\mathrm{X}$-rays. It is not surprising that thero was a great increase in regulations following the development and use of nuclear energy, and 16 of tho 26 countries considered introduced legislation after 1945 . In tho United Kingdom, the first general law for the protection of both workers and public came into boing with the passing of the Radioactive Substances Act of 1948, and in the U.S.S.R. the first general regulations appeared in 1953 .

One example, concerning the employment of women on radioactive work, will suffice to demonstrate the importance of national characteristics, namely, that few countries would find it easy to follow Spain in enforcing a law which excludes from work with ionizing radiations all spinsters who are to be married within 3 months.

* World Health Organization. Protection Against Iomizing Radiations: Survey of Existing Legislation. (Offprint from Vol. 15 , No. 2 of the InterOrganization; Iondon: H.M.S.O., 1964.) 6 Sw. francs; $10 \mathrm{~s}$.; 2 dollars.
There is, howover, general agreement between countries on the maximum pormissible doses of radiation, and this is essentially the result of the fact that most legislation is based on the rocommendations of the International Commission on Radiological Protection.

It is right that there should be international agreement about hazards which sometimes arise because of the gratuitous irradiation of people who have had no concern with the production of the source of the ionizing radiations, for example, from the testing of nuclear weapons, or, more peacefully, from the transport of radioactive sources. Furthermore, in view of the public's apprehension about the effects of radiation at the present time, it is, presumably, easier for most countries to fall in line, rather than disagree, with a body so authoritative and internationally constituted as the International Commission on Radiological Protection. Nevertheless, it will be surprising if, eventually, there are not some differences in the standards used in different countries, in any event for sources which are both generated and applied within their own frontiors. Already, the concept of maximum permissible dose is under review by the International Commission itself and there is a growing awareness of the statistical nature of the risks involved. According to present belief, there is no absolute safe limit on dose, only a diminishing risk as the dose decreases. It is not easy to see, therefore, how thore can be international agreement about limits on dose which are equally acceptablo to all countries. A degree of risk which is totally unacceptable in a well-developed country might seem trivial by comparison with the other risks of life, for example, from famine and disease, in a country the development of which may well depend on the uso of nuclear energy. Mankind has always taken risks in order to improve his ultimate well-being, and no doubt, if the need arises, he will do so again in making use of ionizing radiations. $\Lambda$ lroady, there have been some rejections of the standards set by the International Commission on Radiological Protection when their realization becamo either too inconvoniont or too expensive. For example, some countries find it impracticable in certain industries to reach the present International Commission on Radiological Protection standard relating to the concentration of radon in air, a fact which is acknowledged by the Inter. national Atomic Fnergy Agency in its Safety Series No. 9, 1962. However, other countries, as exemplified in the World Health Orgnnization's survey, have adopted the higher standards and presumably intend to reach them by 